\title{
Runoff potential estimation of Anjana Khadi Watershed using SWAT model in the part of lower Tapi Basin, West India
}

\author{
Dhruvesh P. Patel $^{1,2}{ }_{(\mathbb{C})} \cdot$ Naresh Nandhakumar $^{3}$
}

Received: 31 January 2015/Accepted: 19 December 2015/Published online: 12 January 2016

(C) Springer International Publishing Switzerland 2016

\begin{abstract}
Anjana Khadi watershed is situated at downstream of Ukai dam, covers $836 \mathrm{~km}^{2}$ area and consists of 25 microwatersheds. Water drain from the Anjana Khadi to Tapi River is one of the responsible factors for flooding at Surat city. Present work is focused on flooding potentiality of Anjana Khadi micro-watersheds using the soil and water assessment tools (SWAT). IRS P6 LISS III and Shuttle Radar Topography Mission (SRTM) C band radar data is used for preparation of various input file like land use/land cover, slope, drainage and watershed boundaries in GIS environment. SWAT model is used to simulate the runoff for the monsoon of 2006. Daily, weekly, monthly and annual runoffs are estimated for each micro-watershed. The results obtained show that WS-22 micro-watershed has maximum flood potential while WS-25 as least. In addition, runoff classification map is prepared based on per unit area runoff (PUAR) and for that 25 micro-watersheds are categorized into three runoff classes viz. low $(<1$ $\left.\mathrm{m}^{3} / \mathrm{s}\right)$, moderate $\left(1-6 \mathrm{~m}^{3} / \mathrm{s}\right)$ and high $\left(>6 \mathrm{~m}^{3} / \mathrm{s}\right)$. The analyzed map shows that WS-10, 19, 20, 21, 22 and 23 are fall in the high runoff category. With this, to prevent the flooding suitable remedial measures are also suggested.
\end{abstract}

Keywords Flood mapping - Runoff · AVSWAT . Watershed · Lower Tapi basin · RS and GIS

Dhruvesh P. Patel

dhruvesh1301@gmail.com

1 Department of Civil Engineering, S.P.B. Patel Engineering College, Saffrony Institute of Technology, Linch, Mehsana 384435, Gujarat, India

2 Department of Civil Engineering, Pandit Deendayal Petroleum University, Gandhinagar 382007, Gujarat, India

3 WTI Advance Technology Ltd, Chennai 600086, Tamil Nadu, India

\section{Introduction}

A watershed is a hydrologic unit which produces water as an end product by interaction of precipitation and the land surface. The quantity and quality of water produced by the watershed are an index of amount and intensity of precipitation and the nature of watershed management (Jain et al. 2010; Panhalkar 2014). In some watersheds the aim may have to harvest maximum total quantity of water throughout the year for irrigation and drinking purpose while others may have objective to reduce the peak rate of runoff for minimizing flooding effect and reduce the soil erosion. Hence modeling of runoff is essential for sustainable development (Jain et al. 2010).

The reliable estimation of various hydrological parameters including runoff for remote and inaccessible areas is tedious and time consuming by conventional methods (Panhalkar 2014). Now-a-days, computer-modeling techniques assist scientists and engineers for delineation and parameterization of watersheds by help of geographic information system (GIS) and remote sensing (RS) technology (Pandey et al. 2006). Several physically based distributed parameter models like AGNPS (Young et al. 1989), SHE (Abbott et al. 1986), HECHMS (Feldman 1981), HEC 2000), SWRRB (Arnold et al. 1990; Williams et al. 1985) and SWAT (Arnold et al. 1996) have been developed to predict runoff, erosion, sediment and nutrient transport from rural and agricultural watersheds under various management regimes. Among these models, soil and water assessment tool (SWAT) is the most recent one (Singh and Woolhiser 2002), and is used successfully for simulating runoff, sediment yield and water quality of large basin (Du et al. 2013; Kannan et al. 2007; Narsimlu et al. 2013; Panhalkar 2014; Saha et al. 2014; Yang et al. 2008). Qiu et al. (2012) successfully presented the methodology of evaluating soil and water assessment tool (SWAT) and tested the 
feasibility of SWAT on runoff and sediment load simulation in the Zhifanggou watershed located in hilly-gullied region of china. Therefore, to test the capability of the model in determining the runoff of the watershed, AVSWAT2000/X with ArcView GIS version 3.1 interfaces was selected for the present study. The main objective of the present study is to derive the parameters required for runoff modeling using geospatial technique and estimate the runoff potentiality of Anjana Khadi micro-watersheds. High amount of water discharge in short time period from Anjana Khadi to Tapi River may be one of the major factors of flooding at Surat city. In present work, to map the flood potential of Anjana Khadi micro-watersheds, soil and water assessment tools (SWAT) model in GIS environment is used and by using the results, surplus amount of water in Tapi can be gauged and will be obliging to protect the city against flood.

\section{SWAT model}

SWAT model is computationally efficient, uses readily available inputs and enables users to study long-term impacts (Neitsch et al. 2001). The SWAT model is a distributed parameter continuous model developed by the USDA-ARS (Arnold et al. 1996). The major advantage of the model is that unlike other conventional conceptual simulation models, it does not require much calibration (Gosain et al. 2005). In the model, a watershed is divided into a number of sub-basins based on a given digital elevation model (DEM) map. Within each sub-basin, soil and landuse maps are overlaid to create a number of unique hydrologic response units (HRUs) (Jain et al. 2010). The hydrologic component of SWAT is based on the following water balance equation:

$\mathrm{SW}_{t}=\mathrm{SW}_{o}+\sum_{i=1}^{n}\left(R_{\text {day }}-Q_{\text {surf }}-E_{a}-W_{\text {seep }}-Q_{\mathrm{gw}}\right)$

where $\mathrm{SW}_{t}$ is the final soil water content $\left(\mathrm{mmH}_{2} \mathrm{O}\right), \mathrm{SW}_{o}$ is the initial soil water content $\left(\mathrm{mm} \mathrm{H}_{2} \mathrm{O}\right), \mathrm{t}$ is time in days, $R_{\text {day }}$ is amount of precipitation on day $i\left(\mathrm{~mm} \mathrm{H}_{2} \mathrm{O}\right), Q_{\text {surf }}$ is the amount of surface runoff on day $i\left(\mathrm{~mm} \mathrm{H}_{2} \mathrm{O}\right), E_{a}$ is the amount of evapotranspiration on day $i\left(\mathrm{~mm} \mathrm{H}_{2} \mathrm{O}\right), W_{\text {seep }}$ is the amount of percolation and bypass exiting the soil profile bottom on day $i\left(\mathrm{~mm} \mathrm{H}_{2} \mathrm{O}\right), Q_{\mathrm{gw}}$ is the amount of return flow on day $i\left(\mathrm{mmH}_{2} \mathrm{O}\right)$ (Jain et al. 2010).

\section{Study area}

Tapi basin is divided in three parts, viz. Upper Tapi basin, Middle Tapi Basin and Lower Tapi Basin (LTB) (Patel and Dholakia 2010a; Patel and Srivastava 2013). The segment between Ukai Dam and Arabian Sea is known as LTB in which Surat city falls. In the history of floods at Surat, flood of year 2006 is recorded as a major event which had created a disaster, mass demolition of properties worth INR 20 thousand million and affected human lives and about 300 people died in this terrible flood event. The factors contributing to the occurrence of such a major event included, (1) low discharge carrying capacity of channel (river), (2) uncertain discharge leads by Anjana Khadi watershed-lack of gauge network, (3) lack of information about inundation of water in low laying area, (4) tidal flood due to Arabian Sea, (5) lack of advance flood forecasting system (Parmar and Rao 2002; Patel and Dholakia 2010a, b; Patel and Srivastava 2013). Out of all factors, focus is attributed to discharge by Anjana Khadi watershed as it leads to surplus discharge in Tapi River at LTB and as it is ungauged, discharge from it is extremely uncertain. In case of heavy rainfall in LTB, flood potential of Anjana Khadi can be a major cause of flood at Surat and it must be mapped.

The Anjana Khadi Watershed as shown in (Fig. 1) is a part of the LTB covering about $836 \mathrm{~km}^{2}$ area, bounded by North latitudes $21^{\circ} 00^{\prime \prime}$ to $21^{\circ} 30^{\prime \prime}$ and East longitudes $73^{\circ} 15^{\prime \prime}$ to $73^{\circ} 45^{\prime \prime}$ (Survey of India, scale 1:50,000). Mandvi, Songadh, Ukai, Puna are the major towns in the study area. Anjana Khadi Watershed is sited immediately after downstream of the Ukai reservoir, which is the main reservoir on the river Tapi and extends up to the Mandvi city located at $10 \mathrm{~km}$ downstream to the Kakarapar Weir. The distance between the Kakarapar Weir and Ukai dam is $25 \mathrm{~km}$, thus the total study area is of $35 \mathrm{~km}$. The topography in LTB comprises narrow valley and gently sloping ground (CWC 2000-2001). The LTB receives an average annual rainfall of $1376 \mathrm{~mm}$ (State Water Data Center; Government of Gujarat, 2000) and these heavy downpours result into devastating floods and water loggings in downstream. To calculate discharge of individual watershed, Anjana Khadi watershed is divided into 25 microwatershed namely WS-1 to WS-25 (Table 1). Among all micro-watersheds, WS-23 has the largest area of $77.58 \mathrm{~km}^{2}$ while least area $10.23 \mathrm{~km}^{2}$ is of WS-8.

\section{Data collection}

The data set used for the present work to compute the surface runoff was acquired in summer 2007. Daily rainfall data of seven rain-gauge stations, located at Kadod, Puna, Mandvi, Kakrapar, Ukhalda, Songadh and Ukai, for 2006 flood were collected from State Water Data Center (SWDC), Gandhinagar. The rain fall data of year 2006 was taken into account for estimating the runoff of the Anjana Khadi watershed. Daily temperature and humidity data of 


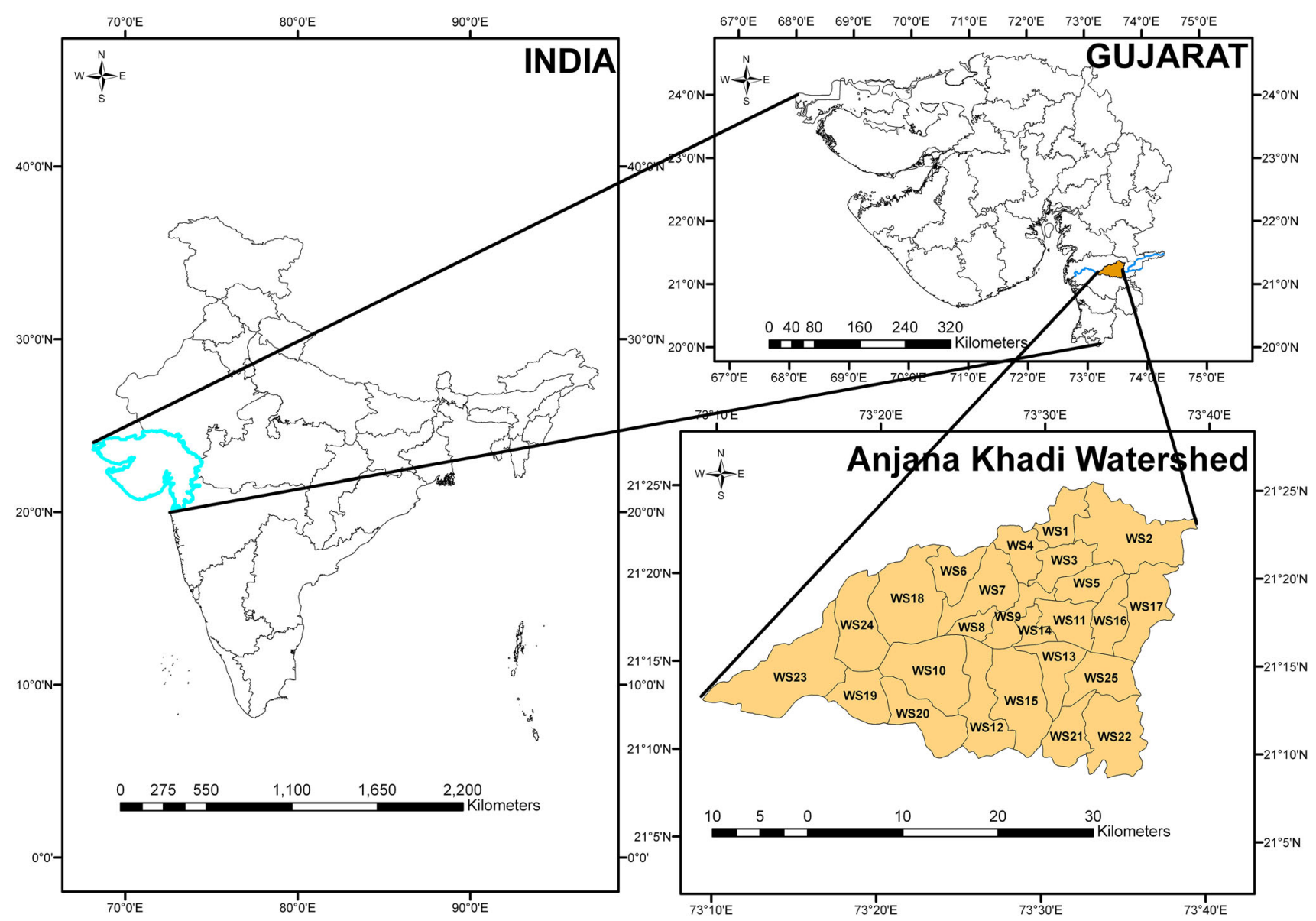

Fig. 1 Location map of Anjana Khadi group of 25 micro-watersheds

Surat station for year 2006 were obtained from Indian Metrological Department (IMD, Ahmedabad). Multi-temporal satellite images, IRS P6 LISS III data of 2005-2006 periods was utilized for Land use/Land cover generation. Soil map of study area has been collected from National bureau of Soil Survey and Land Use Planning (NBSS \& LUP). Topographical sheets no. 46G/3, 4, 7, 8, 11 and 12 having 1:50,000 scale map of study area has been collected from Survey Of India (SOI), Ahmedabad. The Shuttle Radar Topography Mission (SRTM) $90 \mathrm{~m} \mathrm{C}$ band radar obtained elevation data on a near-global scale has been utilized of the area.

\section{Methodology}

\section{Landuse/landcover classification}

LULC changes are important elements of the global environmental change processes (Jaiswal et al. 1999, 2001; Srivastava et al. 2008, 2010, 2011, 2012). Satellite remote sensing-based classification is the statistical technique to group population of pixels in broad classes as per their inherent characteristics (DN value) which are of two types-supervised and unsupervised. A hybrid classification technique (unsupervised classification followed by supervised), was used to determine the LULC of the study area. Unsupervised classification was carried out on the three datasets of the images separately, using a histogram peak cluster technique to identify dense areas or frequently occurring pixels (Jensen 1996; Lillesand and Kjefer 1997). Thus, using the spectral signature and color, the classes initially identified were vegetation and nonvegetation layer. Once the vegetation and non-vegetation classes were separated, training site based classification technology supervised classification technique was used. This technique involved selection of training sites on the image, which represent specific land classes to be mapped. Supervised based classification requires training sets as the reference signatures, which are used to classify the whole population of pixels. The crop and plantation layers were separated from vegetation layer. Built-up, water body and fallow land were separated from non-vegetation layer. The processed vegetation and non-vegetation layers 
Table 1 Area, SWAT runoff, $\%$ slope, $\%$ land use and $\%$ soil group

\begin{tabular}{|c|c|c|c|c|c|c|c|c|c|c|c|c|c|c|}
\hline \multirow{3}{*}{$\begin{array}{l}\text { Watershed } \\
\text { no. }\end{array}$} & \multirow{3}{*}{$\begin{array}{l}\text { Area } \\
\text { in } \mathrm{km}^{2}\end{array}$} & \multirow{3}{*}{$\begin{array}{l}\text { Runoff } \\
\left(\mathrm{m}^{3} / \mathrm{s}\right) \\
\text { total } \\
\text { watershed } \\
\text { SWAT }\end{array}$} & \multirow{3}{*}{$\begin{array}{l}\text { Runoff }\left(\mathrm{m}^{3} / \mathrm{s}\right) \text { (per unit } \\
\text { area of watershed }\end{array}$} & \multicolumn{3}{|l|}{$\%$ Slope } & \multicolumn{8}{|c|}{$\%$ Area in each class } \\
\hline & & & & \multirow{2}{*}{$\begin{array}{l}\begin{array}{l}\text { Gently } \\
\text { sloping }\end{array} \\
(3-8 \%)\end{array}$} & \multirow{2}{*}{ 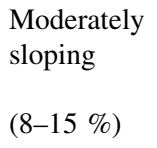 } & \multirow{2}{*}{$\begin{array}{l}\text { Very } \\
\text { gently } \\
\text { sloping } \\
(1-3 \%)\end{array}$} & \multicolumn{5}{|c|}{ Land use } & \multicolumn{3}{|c|}{$\begin{array}{l}\text { Hydrological } \\
\text { soil group }\end{array}$} \\
\hline & & & & & & & 1 & 2 & 3 & 4 & 5 & A & B & $\mathrm{C}$ \\
\hline 5 & 20.47 & 0 & 0 & 00 & 100 & 00 & 0 & 0 & 100 & 0 & 0 & 0 & 0 & 10 \\
\hline 11 & 23.40 & 0 & 0 & 00 & 100 & 00 & 0 & 15 & 80 & 5 & 0 & 40 & 0 & 60 \\
\hline 25 & 29.82 & 0.26 & 0.01 & 00 & 00 & 100 & 5 & 80 & 5 & 7 & 3 & 10 & 90 & 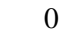 \\
\hline 16 & 23.02 & 0.54 & 0.02 & 00 & 100 & 00 & 0 & 5 & 90 & 0 & 5 & 15 & 5 & 80 \\
\hline 17 & 36.61 & 0.63 & 0.02 & 00 & 100 & 00 & 0 & 5 & 90 & 0 & 5 & 15 & 5 & 80 \\
\hline 13 & 24.96 & 3.91 & 0.16 & 00 & 00 & 100 & 0 & 90 & 1 & 4 & 5 & 60 & 40 & ( \\
\hline 2 & 64.50 & 16.84 & 0.25 & 05 & 90 & 00 & 1 & 5 & 90 & 0 & 4 & 5 & 0 & 95 \\
\hline 7 & 35.93 & 10.21 & 0.28 & 00 & 100 & 00 & 1 & 4 & 95 & 0 & 0 & 5 & 0 & 95 \\
\hline 3 & 20.39 & 9.17 & 0.46 & 00 & 100 & 00 & 0 & 0 & 100 & 0 & 0 & 0 & 0 & 100 \\
\hline 6 & 21.36 & 26.66 & 0.83 & 00 & 100 & 00 & 0 & 6 & 90 & 0 & 4 & 0 & 0 & 100 \\
\hline 4 & 20.94 & 19.97 & 0.89 & 00 & 100 & 00 & 0 & 2 & 98 & 0 & 0 & 0 & 0 & 100 \\
\hline 14 & 10.51 & 12.22 & 1.16 & 00 & 100 & 00 & 0 & 40 & 55 & 0 & 5 & 60 & 0 & 40 \\
\hline 1 & 20.00 & 31 & 1.55 & 05 & 90 & 00 & 0 & 10 & 90 & 0 & 0 & 0 & 0 & 100 \\
\hline 18 & 59.38 & 234.17 & 3.94 & 10 & 60 & 30 & 2 & 45 & 45 & 3 & 5 & 40 & 0 & 60 \\
\hline 15 & 52.03 & 210.77 & 4.05 & 20 & 00 & 80 & 0 & 80 & 10 & 5 & 5 & 30 & 50 & 20 \\
\hline 9 & 19.48 & 82 & 4.35 & 00 & 100 & 00 & 0 & 20 & 75 & 0 & 5 & 40 & 0 & 60 \\
\hline 8 & 10.23 & 54.24 & 5.3 & 00 & 100 & 00 & 0 & 10 & 85 & 0 & 5 & 70 & 0 & 30 \\
\hline 12 & 39.14 & 208.11 & 5.32 & 60 & 00 & 40 & 0 & 70 & 10 & 15 & 5 & 30 & 20 & 50 \\
\hline 19 & 25.89 & 379.16 & 7.18 & 00 & 00 & 100 & 0 & 85 & 0 & 5 & 10 & 60 & 40 & 0 \\
\hline 23 & 77.58 & 461.79 & 7.58 & 60 & 00 & 40 & 5 & 65 & 5 & 5 & 0 & 85 & 15 & 0 \\
\hline 10 & 53.29 & 406.02 & 7.62 & 10 & 20 & 70 & 3 & 80 & 0 & 10 & 7 & 30 & 50 & 20 \\
\hline 20 & 34.84 & 293.44 & 8.42 & 05 & 00 & 95 & 5 & 75 & 5 & 10 & 5 & 10 & 85 & 5 \\
\hline 21 & 24.47 & 270.23 & 11.04 & 10 & 00 & 90 & 0 & 80 & 10 & 10 & 0 & 0 & 80 & 20 \\
\hline 24 & 40.73 & 546.43 & 13.09 & 60 & 00 & 40 & 5 & 75 & 5 & 5 & 10 & 90 & 0 & 10 \\
\hline 22 & 45.55 & 762.87 & 16.75 & 10 & 00 & 90 & 5 & 55 & 8 & 30 & 2 & 0 & 100 & 0 \\
\hline
\end{tabular}

are finally mosaiced to generate one single land use/land cover layer.

\section{Slope and soil of the study area}

Soil is classified into categories in order to understand relationships between different soils and to determine the usefulness of a soil for a particular use. Soil resources are critical to the environment which provides minerals and water to plants. Soil absorbs rainwater and releases it later, thus regulating floods and drought. Topography show the local and regional relief setting gives an idea about the general direction of surface water flow. The SRTM model of the area has been utilized to generate the slope map of the watershed. Low slope $(0-5 \%)$ indicates presence of low rate runoff flow whereas high slope $(>20 \%)$ shows presence of high surface water flow (Gupta and Srivastava 2010; Srivastava et al. 2011).

\section{Drainage delineation and density estimation}

Drainage density, a fundamental concept in hydrologic analysis, is defined as the length of drainage per unit area. It is an inverse function of permeability and therefore is an important factor in groundwater evaluation. The term was first introduced by (Horton 1932) and is determined by dividing the total length of streams within a drainage basin by the drainage area. A high drainage density reflects a highly dissected drainage basin with a relatively rapid hydrologic response to rainfall events, while a low drainage 


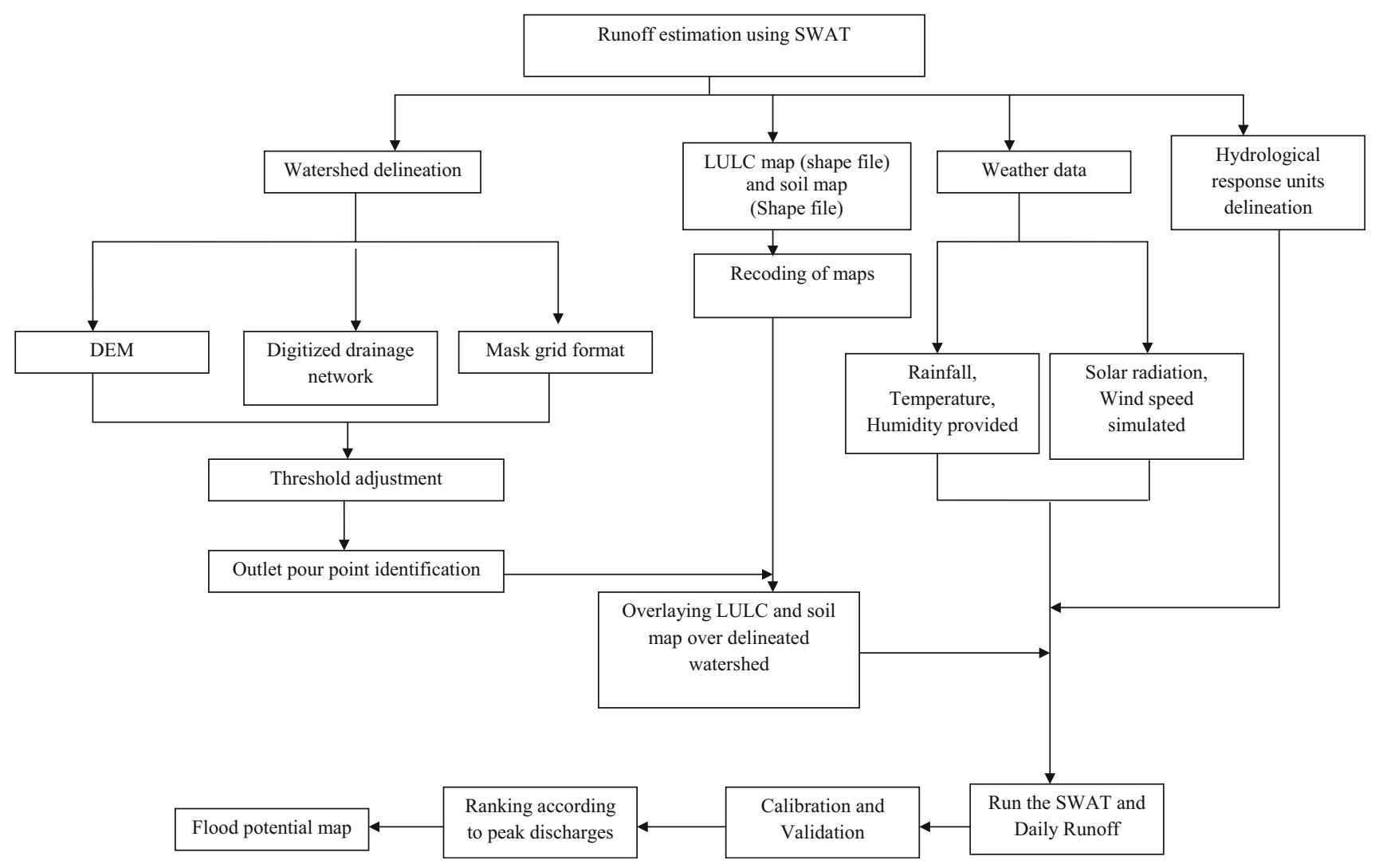

Fig. 2 Methodology adopted for runoff potential assessment of Anjana Khadi watersheds

density means a poorly drained basin with a slow hydrologic response (Melton 1957). The drainage density can be defined as (Edet et al. 1998):

$D_{d}=\frac{\sum_{i=1}^{i=n} S_{i}}{A}$

where $\sum_{i=1}^{i=n} S_{i}$ is the total length of drainage.

\section{Hydro-meteorological variables}

\section{Potential evapotranspiration (PET)}

Numerous methods have been developed to estimate potential evapotranspiration (PET). Three of these methods have been incorporated into SWAT: the Penman-Monteith method (Allen 1986; Monteith 1965), the Priestley-Taylor method (Priestley and Taylor 1972) and the Hargreaves method and these three PET methods vary in the amount of required inputs. The Penman-Monteith method requires solar radiation, air temperature, relative humidity and wind speed. The Priestley-Taylor method requires solar radiation, air temperature and relative humidity while the Hargreaves method requires air temperature only. Once total
PET is determined, actual evaporation must be calculated. SWAT first evaporates any rainfall intercepted by the plant canopy. Next, calculates the maximum amount of transpiration and the maximum amount of sublimation/soil evaporation (Ritchie 1972). The actual amount of sublimation and evaporation from the soil is then calculated. In the present study the Hargreaves method is used to calculate the PET.

\section{Weather parameters}

The weather variables necessary for driving SWAT are precipitation, air temperature, solar radiation, wind speed, and relative humidity.

Precipitation, air temperature and solar radiation Daily rainfall of seven stations in and around the study area is given as the input, in the separate file. Daily maximum and minimum air temperature and solar radiation are generated from a normal distribution corrected for wetdry probability state. The correction factor is used to provide more deviation in temperature and radiation when weather changes and for rainy days. Conversely, deviations are smaller on dry days. The correction factors are 


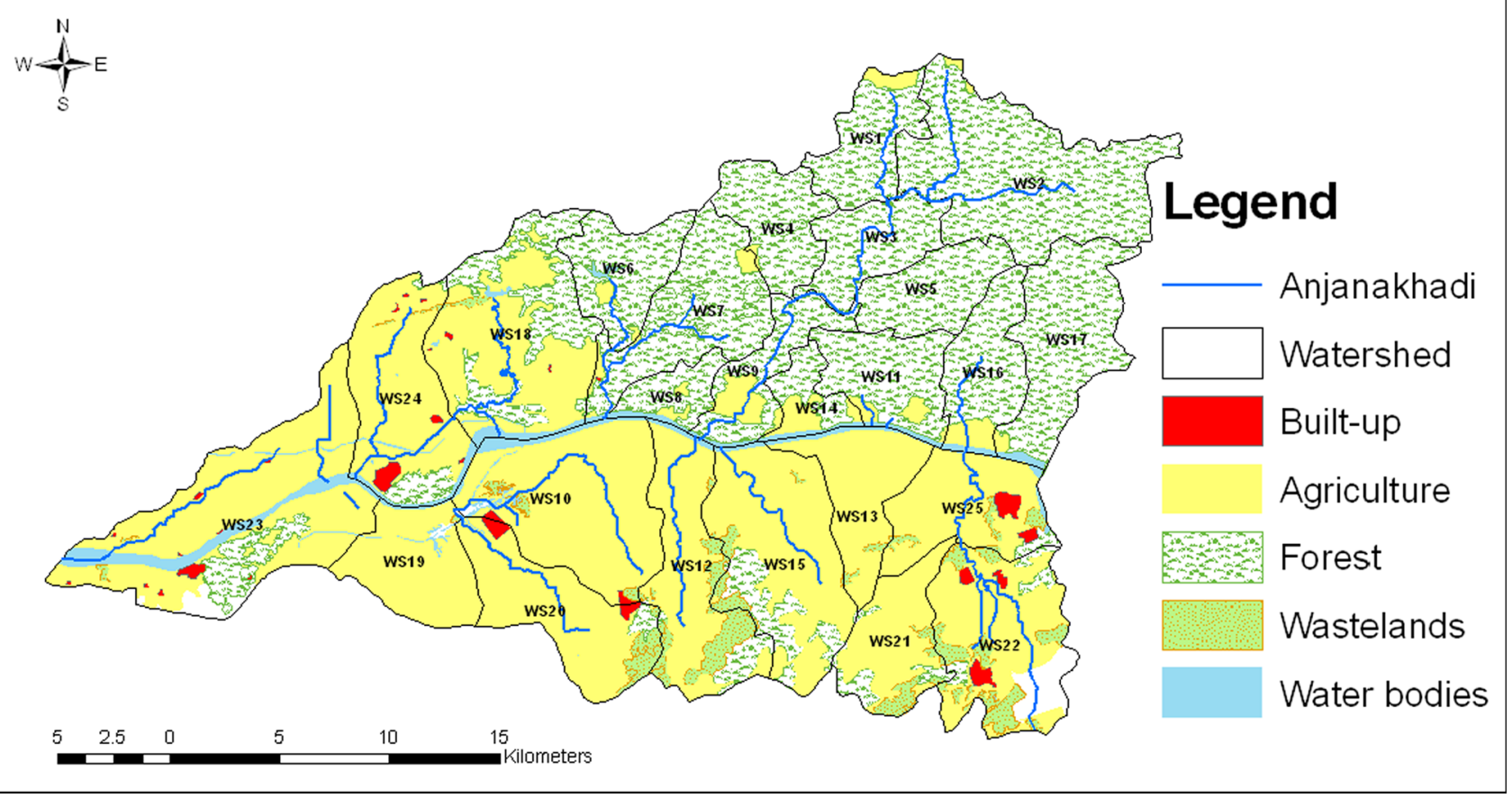

Fig. 3 Land-use land cover distribution map of Anjana Khadi watershed

calculated to ensure that long-term standard deviations of daily variables are maintained. For study area, the air temperature is given as the input and the solar radiation is simulated.

Wind speed and relative humidity Daily wind speed is simulated using a modified exponential equation given the mean monthly wind speed as input. The relative humidity model simulates daily average relative humidity from the monthly average by using a triangular distribution. As with temperature and radiation, the mean daily relative humidity is adjusted to account for wet and dry-day effects. For study area, relative humidity is given as the input and the model simulates the wind speed.

\section{Peak discharge estimation of a stream/river}

The discharge of a channel or river can be estimated by the equation of continuity represented as

$Q=a v$

where $Q$ is the discharge $\left(\mathrm{ft}^{3} / \mathrm{s}\right.$ or $\left.\mathrm{m}^{3} / \mathrm{s}\right), a$ is the crosssectional area of the stream $\left(\mathrm{ft}^{2}\right.$ or $\left.\mathrm{m}^{2}\right)$ obtained by simplifying the geometry and calculating the area or by drawing cross-sections to scale and measuring the area and $v$ is the average velocity of flowing water ( $\mathrm{ft} / \mathrm{s}$ or $\mathrm{m} / \mathrm{s}$ ). For uniform flow in a channel the average velocity, $v$, can be estimated by Manning's equation: $v=\frac{1.5}{n} R^{2 / 3} S^{1 / 2}$

where $v$ is the velocity of flow ( $\mathrm{ft} / \mathrm{s}$ or $\mathrm{m} / \mathrm{s}$ ); $n$ is Manning's roughness coefficient of the channel; $S$ is the channel bed slope $(\mathrm{ft} / \mathrm{ft}$ or $\mathrm{m} / \mathrm{m})$; and $R$ is the hydraulic radius of the channel (ft or $\mathrm{m}$ ) that is calculated as:

$R=\frac{a}{p}$

where $P$ (ft or $\mathrm{m})$, is the wetted perimeter of the channel cross-section.

\section{Modeling and simulation}

SWAT is a physical based model that requires specific information about weather, soil properties, topography, vegetation, and land management practices occurring within the watershed. These data are utilized to estimate the discharge from the Anjana Khadi micro-watersheds and the procedure steps are:

- Delineation of watershed

- Overlaying of land use and soil map

- Hydrological response unit

- Write input file

- Model-simulation

Detailed methodology is shown in (Fig. 2). 


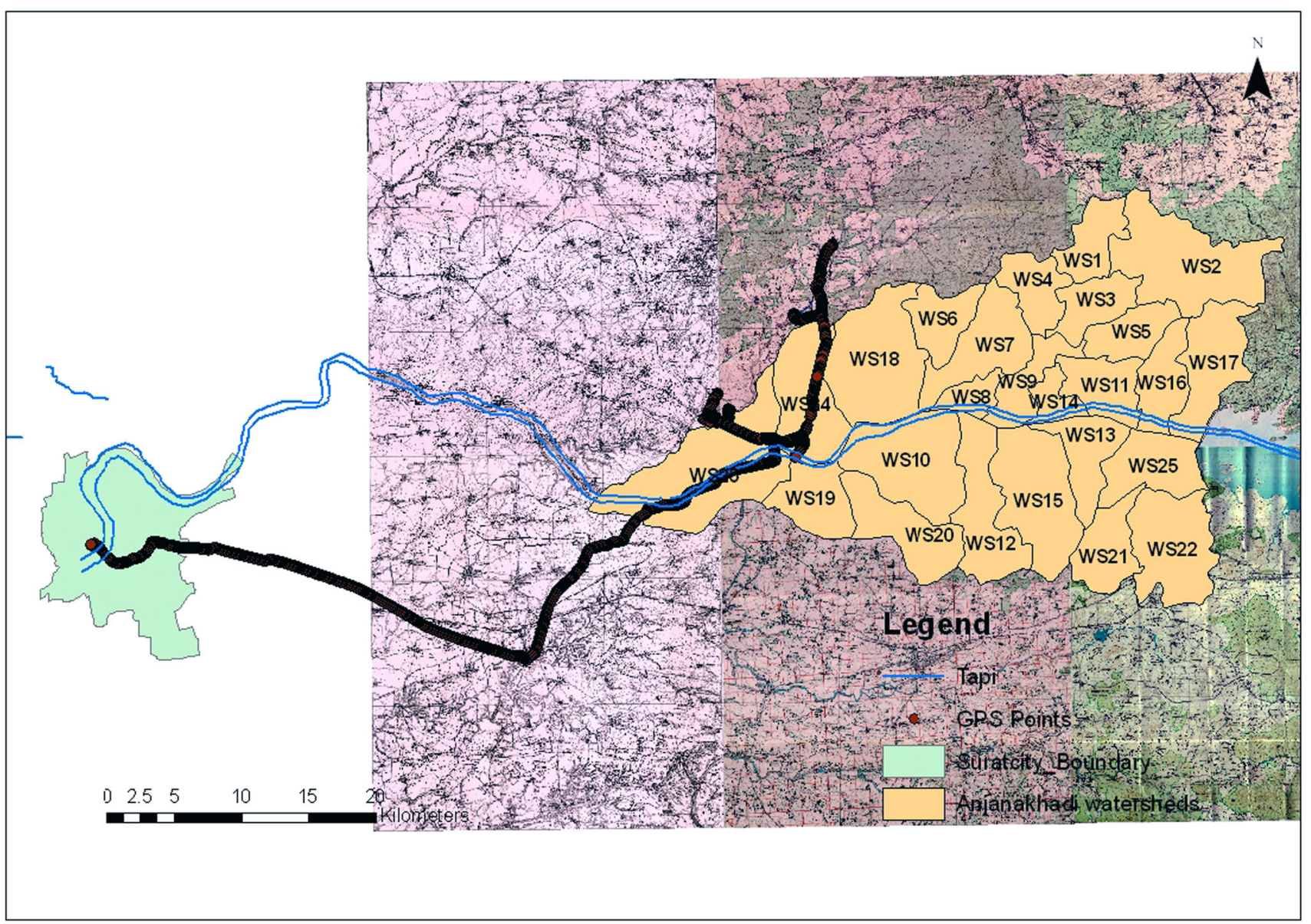

Fig. 4 GPS survey of Anjana Khadi watersheds

\section{Results and discussion}

\section{Landuse/landcover distribution}

The satellite image IRS P6 LISS III data of 2005-2006 periods were utilized and classified into 18 classes. As per the model requirement the land use class is further classify in basic 5 land use classes i.e., (1) built-up, (2) agriculture, (3) forest, (4) wasteland and (5) water body (Fig. 3). The percentage of land use/land cover occupied by the different class is mentioned in (Table 1). On account of analysis of these classified images, we are able to infer certain extent of the spatial composition of different physiographic features. The type and density of vegetation cover and landuse characteristics are also important to understand hydrologic response to rainfall.

The supervised classifications have been validated by GPS (Geo Trimble XT). Figure 4 shows the path and survey field. The major survey has been carried out in WS26, WS-4 and WS-18 for validation of different land-use classes. To achieve this objective sample points are located by Geographic Positioning System (GPS). Where IRS P6
LISS III of year 2006 represented same results with the GPS and Geographic Information System (GIS). The result shows an accuracy of $92.05 \%$ with over all Kappa statistics (ka) of $90.20 \%$, however, remote sensing data, GPS data (ground truth), positional accuracy and logical consistency matches with the information on the map.

\section{Soil and slope analysis}

The two major type of soil order found in the region (Fig. 5) are inceptisol and vertisol. Inceptisols are soils just starting to show horizon development because the soil is quite young. Inceptisols are found in any type of environment and are commonly found forming in alluvium on floodplains and delta deposits, covers $68.24 \%$ of study area. Vertisols are dark black soils rich in expandable clay minerals and covers $31.75 \%$. Though found in every type of climate, they are often found in steppe and wet/dry tropical climates where the soil develops deep cracks as it dries (USDA). Further the soil is classified in three groups i.e., A-fine, B-loamy and C-clayey soil content (Fig. 6). The percentage of different group occupied by the 


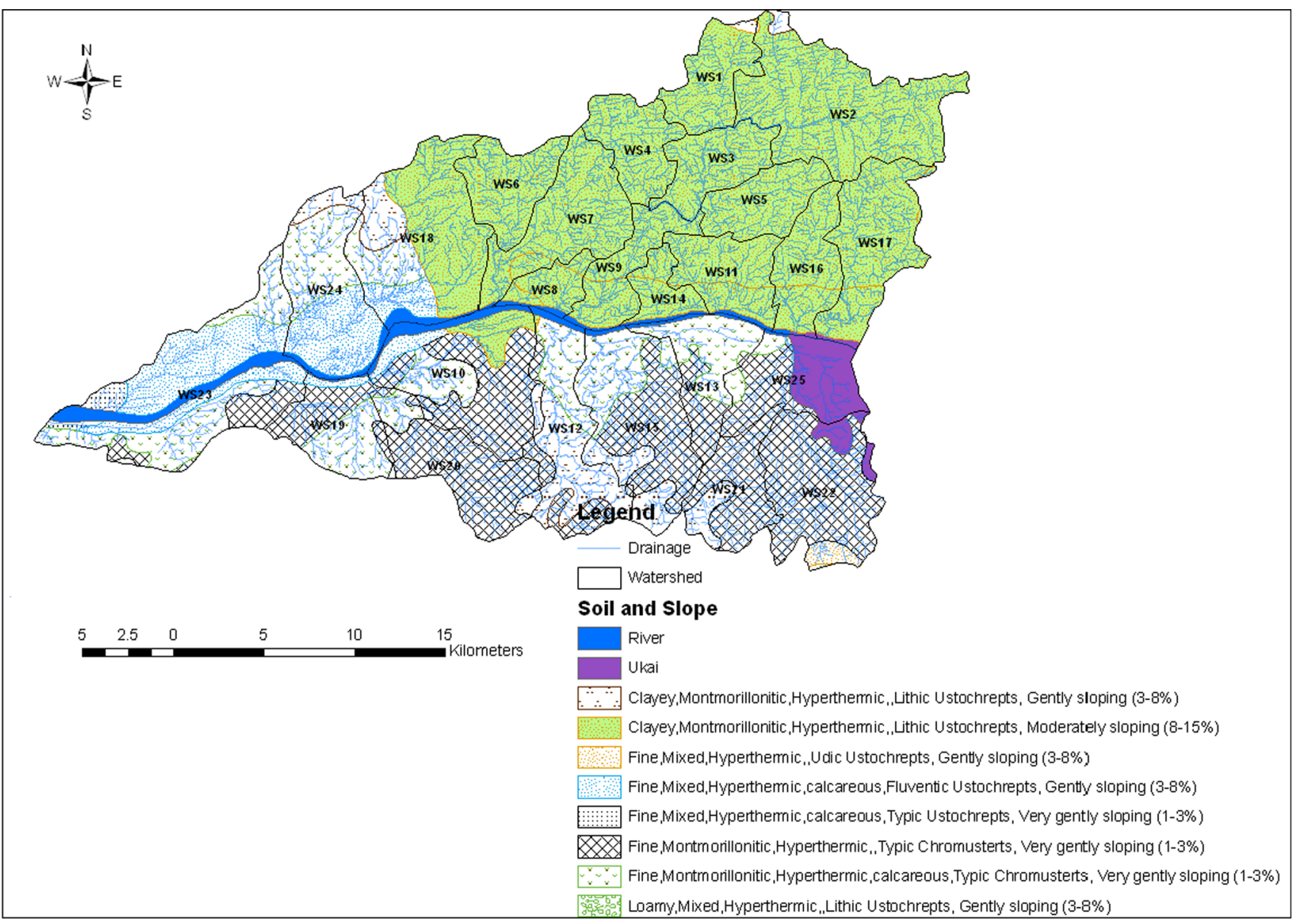

Fig. 5 Soil map and slope map of Anjana Khadi watershed

soil classes is mentioned in (Table 1) hydrological response to rainfall strongly depends on local characteristics of soil, such as water storage capacity and infiltration rates.

The percentage of slope classification has been seen in Table 1 Slope map of the area suggested that most of the terrain in the North-East was characterized by a high slope, may be responsible for a high runoff in this region, while the South and West part of the terrain comes under low slope category may be responsible for a high water logging in this area. Most of the moderate slope category can be seen in North side of the area, may be responsible for intermediate rate of runoff (Fig. 5).

\section{Drainage density analysis}

The effect of drainage density on runoff volume is associated with the time during which the runoff remains in the watershed. Low densities allow for long residence times; therefore, abstraction mechanisms have more time to remove water (Gupta and Srivastava 2010). Thus, drainage density analysis was particularly very important for delineating the watershed. The drainage density map (Fig. 7) indicated that watersheds 3 and 9 are under high drainage density category, followed by rest of the watersheds (moderate drainage density category) with an average value of $2-4 \mathrm{~km} / \mathrm{km}^{2}$, except 13 and 23 which was found under low drainage density category $\left(0-2 \mathrm{~km} / \mathrm{km}^{2}\right)$. This analysis suggested that most of the watershed showed poorly drained basin with a slow hydrologic response. The two watersheds were found to be associated with a high drainage density reflects a highly dissected drainage basin with a relatively rapid hydrologic response to rainfall events.

\section{Precipitation, potential evapotranspiration (PET) and temperature}

The comparisons between rainfall, PET and temperature time series exhibit a high spatial variability with seasons and follow a strong seasonal cycle, peaking normally in June, July and August; typically, a very high temperature during the period of May, June and July. As a comparison to PET, the increasing temperatures and high evaporation 


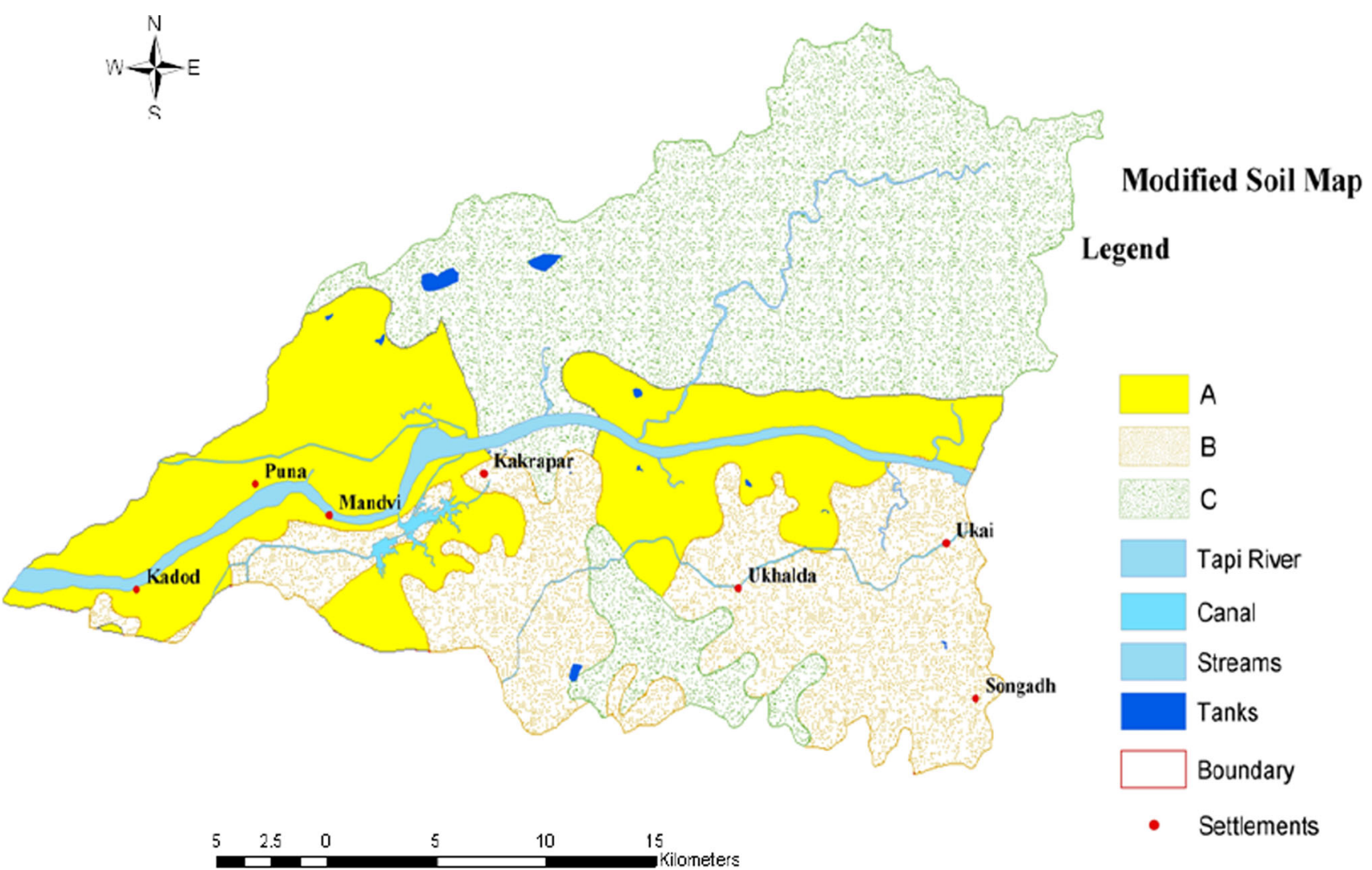

Fig. 6 Modified soil group map of Anjana Khadi watershed

Fig. 7 Drainage density of Anjana Khadi in $\mathrm{km} / \mathrm{km}^{2}$

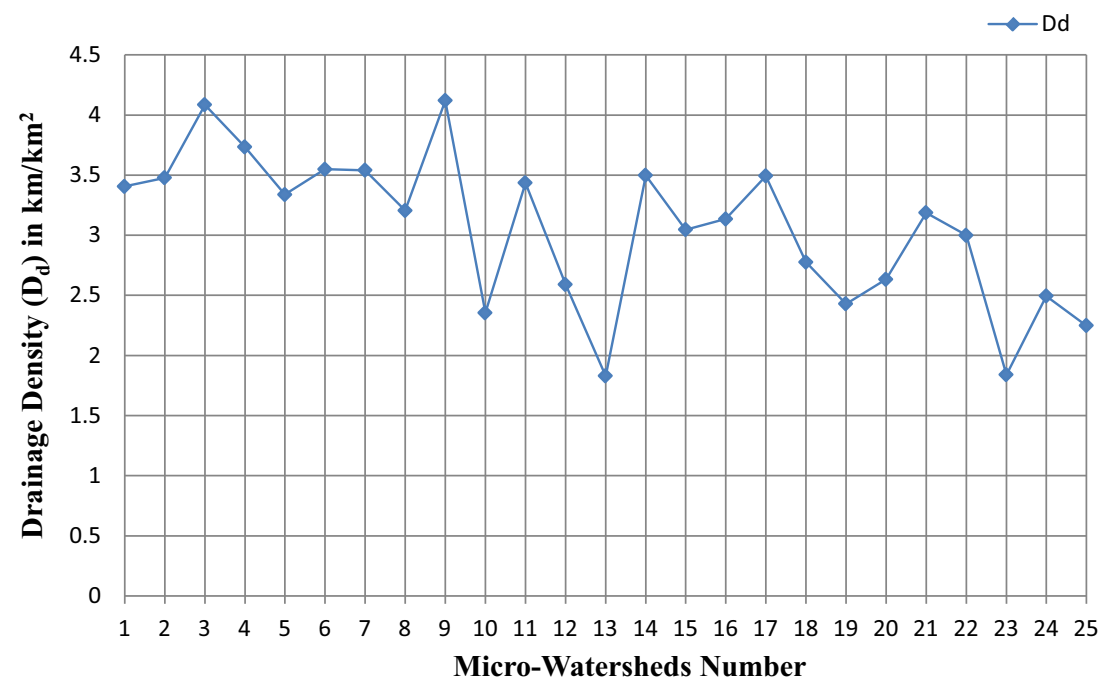

through the period April-May to August-September leads to a progressive drying of the soil. The soil moisture increases after a rain event and it follows an exponential decay as expected. When PET rates slacken in the November-December, decrease the rainfall, wets-up the soil profile-and hence a surging graph can be seen in (Fig. 8).

\section{Surface runoff prediction in SWAT model}

Appling the necessary input files including DEM, drainages, soil, land use/land cover; whether input as temperature and humidity, model is prepared for run. In order to study the behavior of Anjana Khadi watershed, SWAT 
Fig. 8 Precipitation, potential evapotranspiration (PET) and temperature

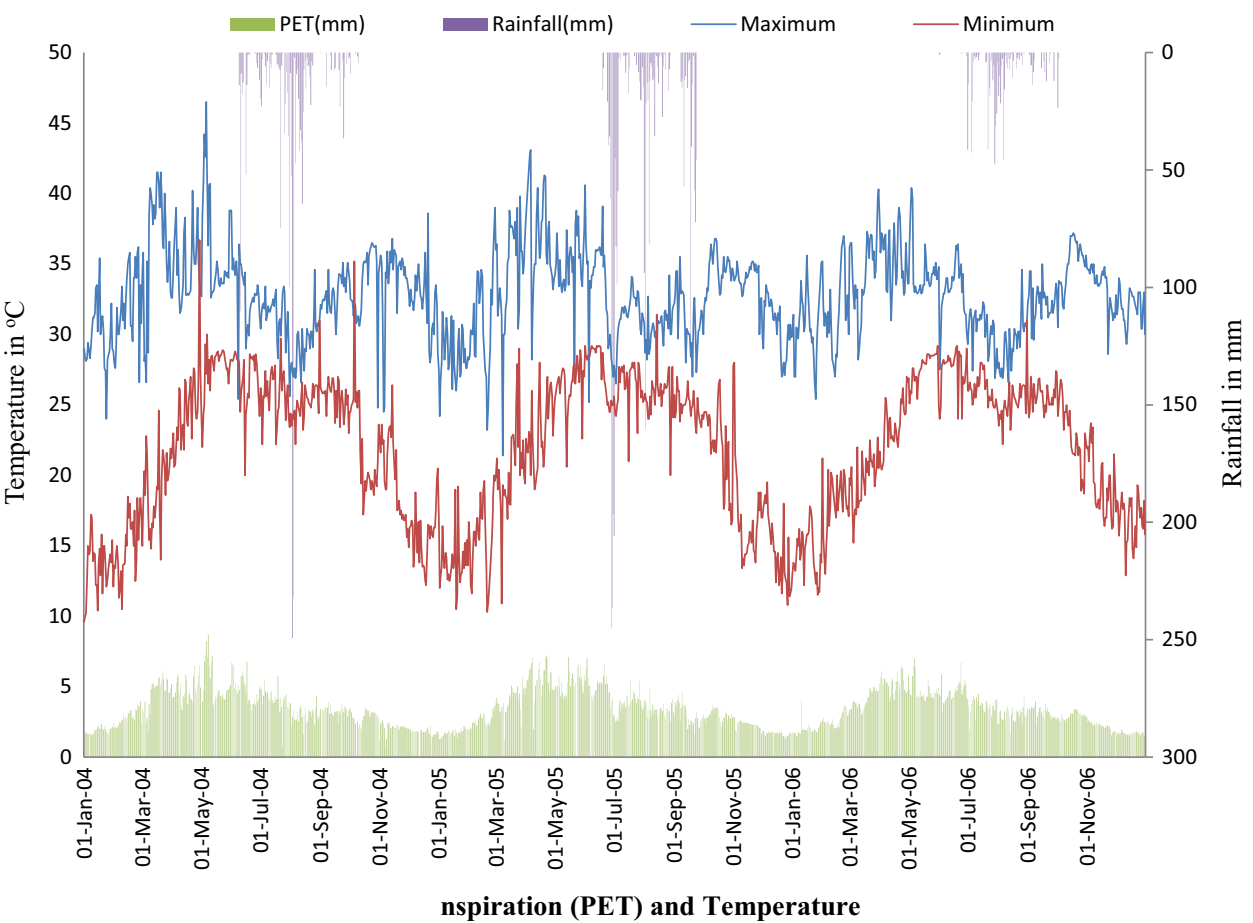

model is simulated for the monsoon period of year 2006 which measures the discharge leaded by its watersheds.

Daily, monthly and yearly runoff has been estimated by the SWAT model. Results show that peak discharge was obtained $762.87 \mathrm{~m}^{3} / \mathrm{s}$ for WS-22 followed by WS-24 $\left(546.34 \mathrm{~m}^{3} / \mathrm{s}\right.$ (Table 2). For WS-3, $9.17 \mathrm{~m}^{3} / \mathrm{s}$ has been obtained while $379.16 \mathrm{~m}^{3} / \mathrm{s}$ is obtained for WS-19. Simulated runoff hydrograph of Anjana Kadi watersheds for period of June-October 2006 is shown in (Fig. 9). It shows the rainfall increase the discharge increase and vice versa. Furthermore, the runoff is classified per unit area runoff for micro-watershed, it was divided in three classes viz. runoff class $1\left(0-1.0 \mathrm{~m}^{3} / \mathrm{s}\right)$, class $2\left(1.1-6.0 \mathrm{~m}^{3} / \mathrm{s}\right)$ and class 3 greater than $\left(6.0 \mathrm{~m}^{3} / \mathrm{s}\right)$. The micro-watersheds characteristics like land use/land cover, soil, slope are studied (Table 1) with respect to the per unit area runoff. Some salient observation made is listed as follows (Figs. 10, 11).

- In class 1 , forest in land use and $\mathrm{C}$ group in hydrological soil group are dominant and hence runoff is very less. In class 1 , there are two watersheds (25 and 13) which show some deviation with respect to the watershed characteristics. In these watersheds the land use is dominated by agriculture land and runoff is less.

- In class 2, agriculture land dominates followed by forest land in the land use. The A and C hydrological soil groups are dominant so that the average runoff is noted. In class 2 , the watersheds are having nearly $5 \%$ of area under water bodies.
- In class 3, agriculture land dominates followed by the presence of wasteland. The B group of the hydrological soil group is dominant in soils. Along with the agriculture land in class 3, waste land of nearly $10 \%$, water bodies of nearly $5 \%$ and habitation of nearly $5 \%$ are also seen (Table 1 ).

- From the integrated map it is noted that, more runoff is in the western side of the study area. In eastern part runoff is very less because the area is dominated by forest and in middle, runoff is moderate as shown in integrated map. But in the eastern part watersheds 21 and 22 are having more runoff because of the more rainfall in the region.

\section{Calibration and validation}

The obtained simulated runoff from the SWAT model for the year 2006 is calibrated with the Soil Conservation Service (SCS) method and validated with the observed gauge data at Ghala gauge station on Tapi river. Anjana Khadi leads its discharge into Tapi river between Ghala and Mandvi gauge-discharge station. None of the gaugedischarge station is established on Anjana Khadi river. Hence, the discharge from the Anjana Khadi watershed is only predicted by sum up the simulated discharge from Anjana Khadi with observe discharge at Mandvi station. Validation can be done by comparing the result with the observe discharge at Ghala station.

Comparison of the simulated runoff volume obtained from the two models shows very good correlation 
Table 2 Peak discharge and flood potential ranks of mini-watersheds

\begin{tabular}{llr}
\hline Watersheds no. & Discharge $\left(\mathrm{m}^{3} / \mathrm{s}\right)$ & Flood potential ranks \\
\hline WS-1 & 31 & 13 \\
WS-2 & 16.84 & 16 \\
WS-3 & 9.17 & 19 \\
WS-4 & 19.97 & 15 \\
WS-5 & 0 & 24 \\
WS-6 & 26.66 & 14 \\
WS-7 & 10.21 & 18 \\
WS-8 & 54.24 & 12 \\
WS-9 & 82 & 11 \\
WS-10 & 406.02 & 4 \\
WS-11 & 0 & 24 \\
WS-12 & 208.11 & 10 \\
WS-13 & 3.91 & 20 \\
WS-14 & 12.22 & 17 \\
WS-15 & 210.77 & 9 \\
WS-16 & 0.54 & 22 \\
WS-17 & 0.63 & 21 \\
WS-18 & 234.17 & 8 \\
WS-19 & 379.16 & 5 \\
WS-20 & 293.44 & 6 \\
WS-21 & 270.23 & 7 \\
WS-22 & 762.87 & 23 \\
WS-23 & 461.79 & \\
WS-24 & 546.34 & 1 \\
WS-25 & 0.26 & \\
\hline & & \\
\hline
\end{tabular}

(Fig. 10). Whereas Fig. 11 shows the moderate correlation between simulated and observed. This is due to nonavailability of data/data gaps with respect to the water

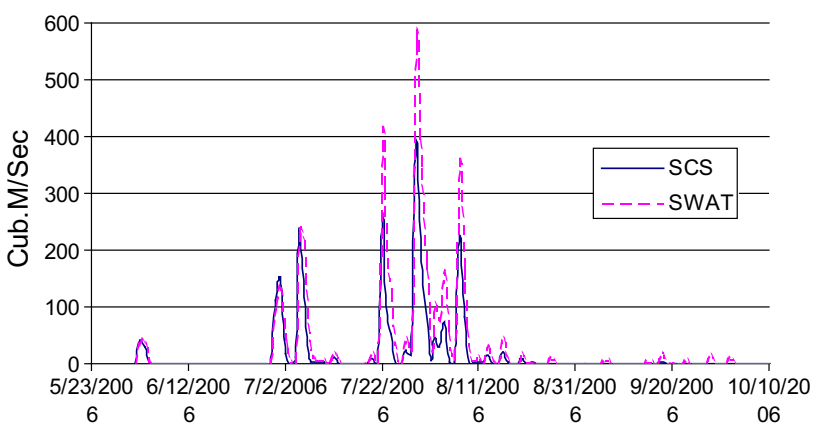

Fig. 10 Calibration of simulated flow with SCS method for the year 2006

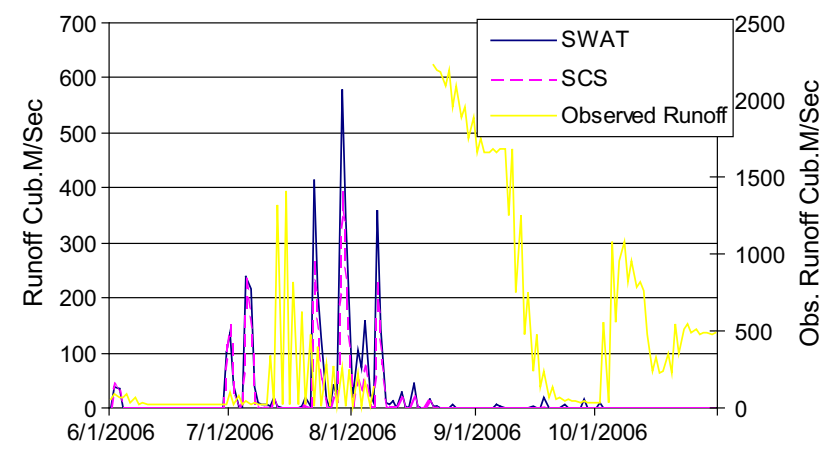

Fig. 11 Validation of simulated flow with observed data for the year 2006

released from the Ukai dam located upstream. This is the preliminary case study on this watershed which will help to reduce uncertainty for quantum of potentiality of runoff of Anjana Khadi watersheds during flooding. It will reduce the hydrological information for the decision maker during flooding.
Fig. 9 Simulated runoff hydrograph of Anjana Khadi watersheds

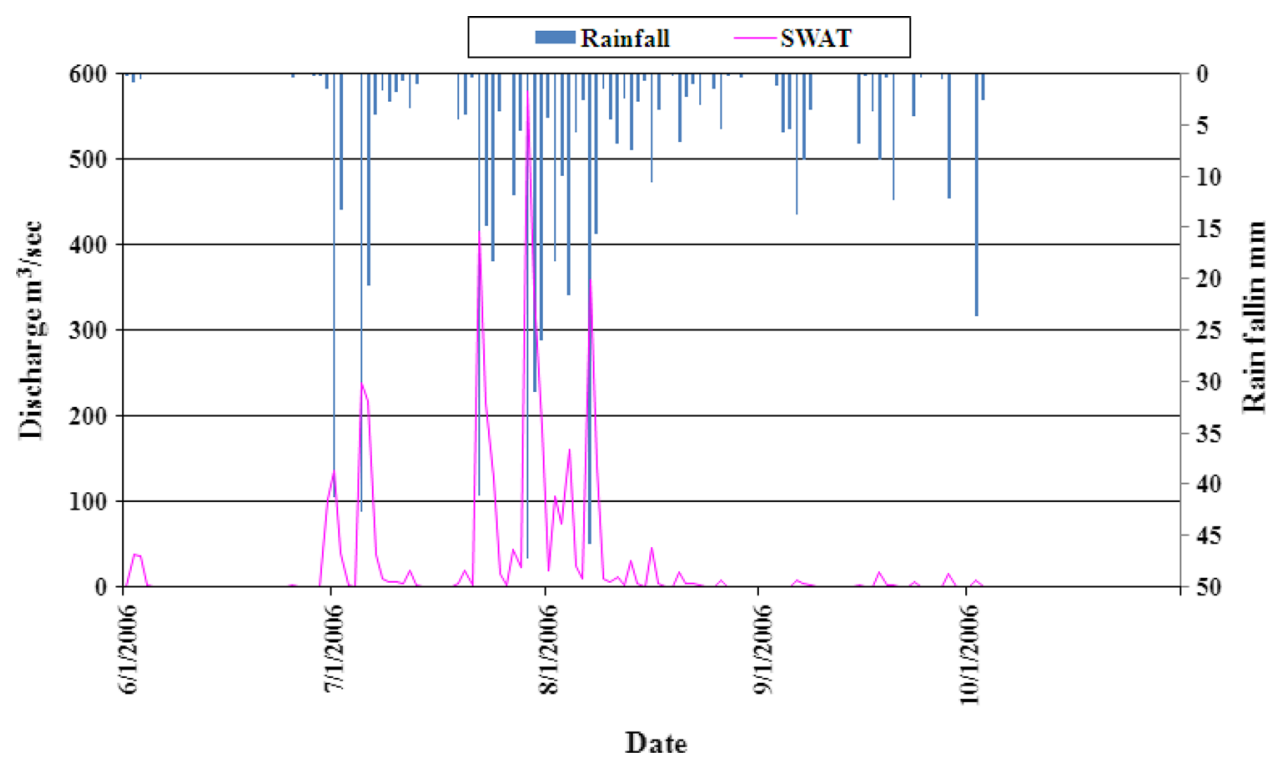




\section{Ranking and prioritization of micro-watersheds}

From the group of Anjana Khadi micro-watersheds, highest rank was assigned to the micro-watershed having the highest discharge. Watershed no. 22 has rank 1 with highest discharge of $762.87 \mathrm{~m}^{3} / \mathrm{s}$ and is followed by watersheds no. 24 and 23, as second and third and so on. These results are gathered in (Fig. 12) which shows flood potentiality of each micro-watershed.

\section{Recommendation and suggestion for flood mitigation}

There are two ways to reduce the amount of runoff coming from Anjana Khadi watersheds, by (1) structural measures and (2) non-structural measures.

The weighted sum overlay analysis in Arc GIS 9.1 using spatial modeler tool has been used to integrate the thematic layers such as soil type, drainage density, Land use/land cover, runoff class, slope from DEM and keeping in view the prioritized rank maps, suitable preliminary check dam construction sites are identified (Fig. 12) (Patel et al. 2012a, b). Geo-visualization concept, which is the part of GIS technique, is helpful to position a suitable site for check dams in Anjana Khadi mini-watersheds no. 1, 5 (Fig. 13) so that it directly check the excessive water coming from the Anjana Khadi micro-watersheds. It leads the soil as well as water conservation and reduces high run off and flood potentiality. Timely placement of these structures may reduce a number of losses and flood in the downstream area.

The existing CWC flood forecasting system seems inadequate for current period because the agency is having limited information in terms of rainfall record, not enough inflow data and absence of recent techniques useful for river monitoring and forecasting system as modern technology is developed day by day (Patel and Srivastava 2013). In present study, 7 rain gauges are located at the right bank of Tapi River in Watersheds no. 19, 23, 10, 15, 25 , and 22. It was found that the annual daily rainfall at Kadod (2017 mm), Puna (1570 mm), Mandvi (2228), Kakrapar (1676 mm), Ukai (1371 mm), Songadh

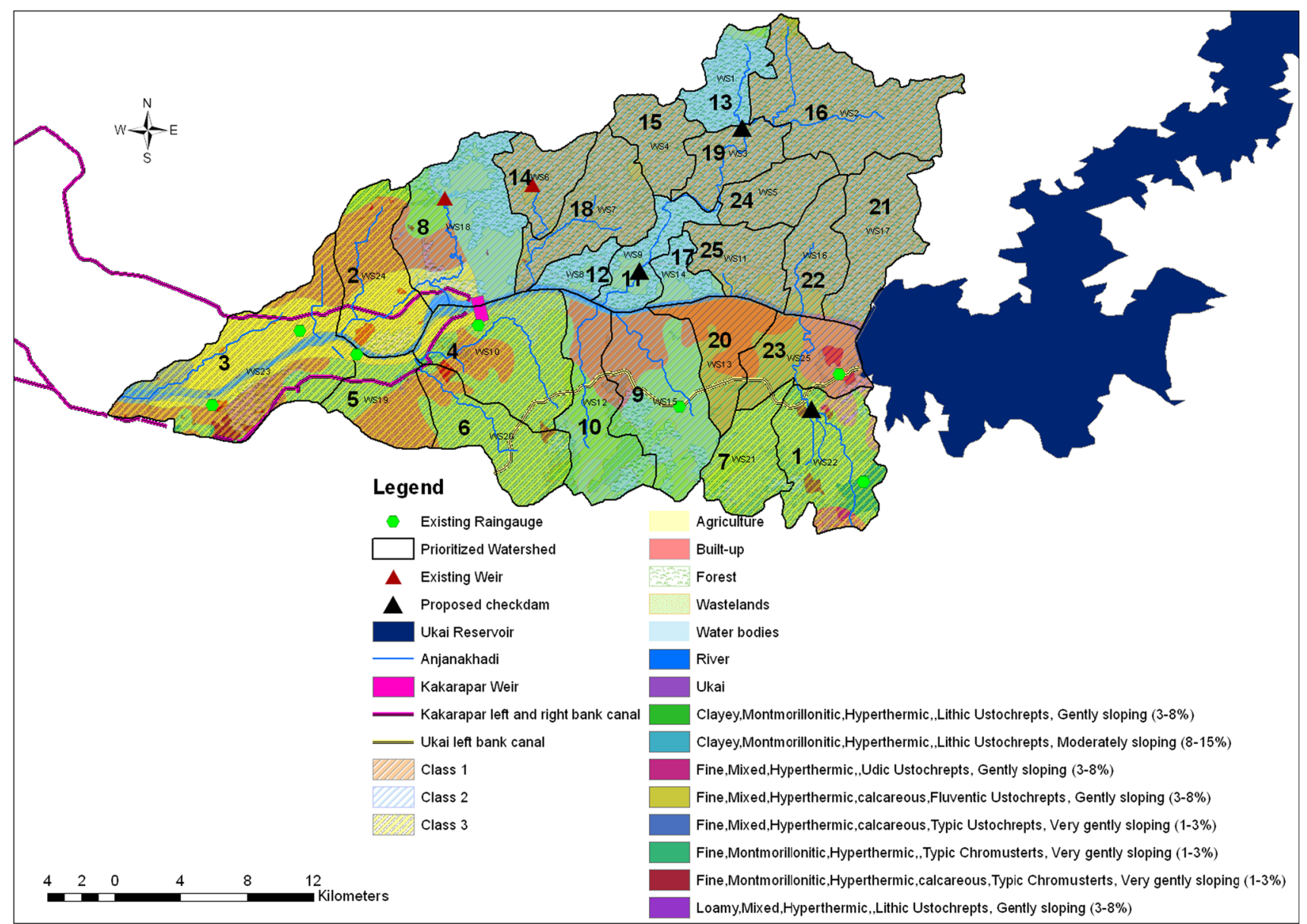

Fig. 12 Integrated map including prioritized Anjana Khadi watershed, runoff classification and check dam location according to flood potentiality 


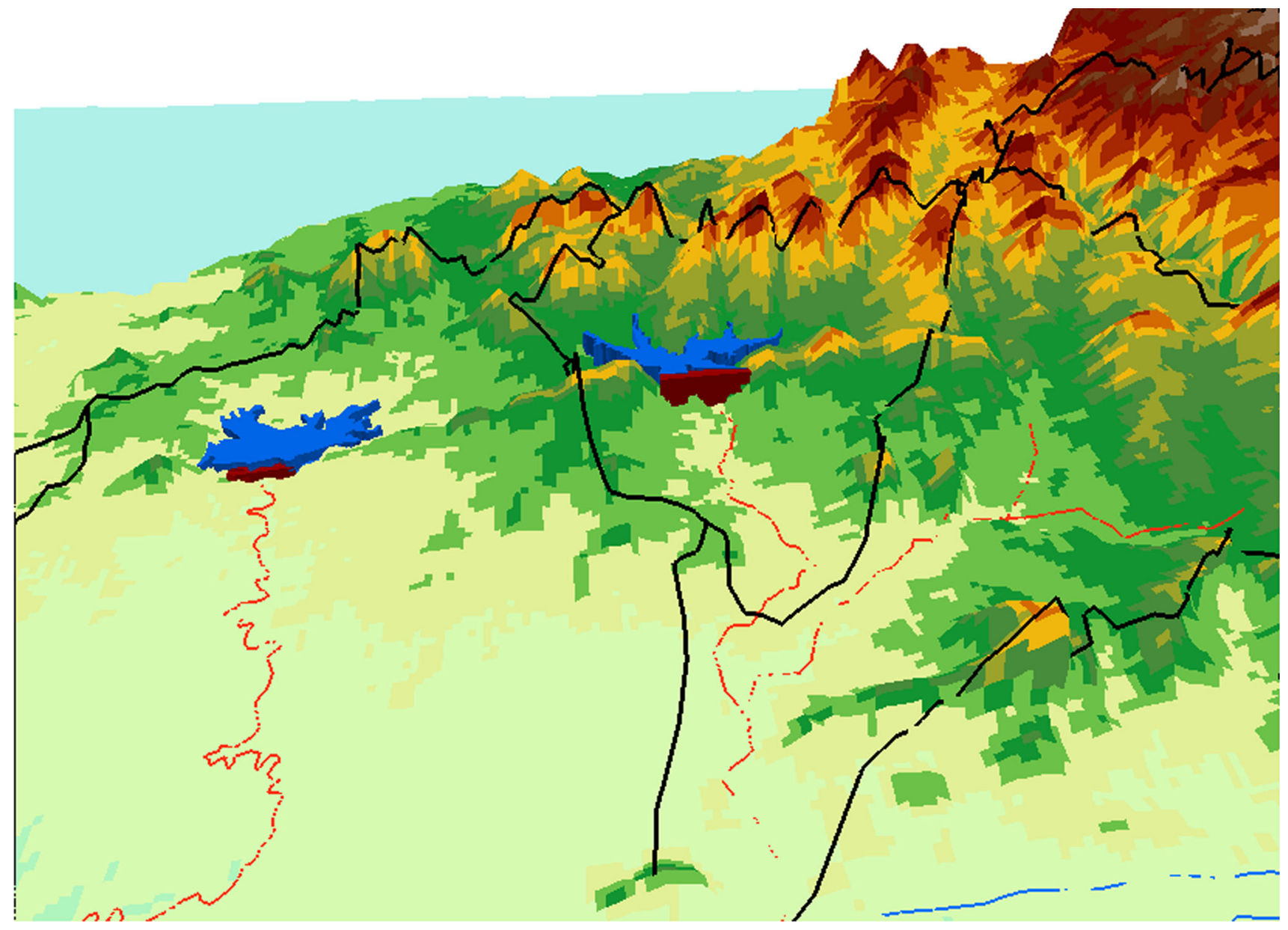

Fig. 13 Check dam location through geo-visualization

(3400 mm) and Ukhalda (1400 mm) in year 2006 (State Water Data Center; Government of Gujarat 2006). As per the Optimum number of rain gauges (Kumar et al. 2005; Subramanya 1994):

$\bar{p}=\frac{\sum P}{n}$

$\overline{P^{2}}=\frac{\sum P^{2}}{n}$

$\sigma=\sqrt{\frac{n}{n-1}\left[\overline{P^{2}}-(\bar{P})^{2}\right]}$

$C_{v}=\frac{100 \sigma}{\bar{P}}$

$N=\left(\frac{C_{v}}{E}\right)^{2}$.

where $\bar{P}=$ Mean rainfall, $\overline{P^{2}}=$ Mean of squares, $\sigma=$ Standard deviation, $\quad C_{v}=\mathrm{Co}-$ efficient of variation, $N=$ Optimum number of rain gauge, $\quad E=$ Allowable percentage error $(10 \%)$
The obtained values from the data are $\bar{P}(1957.71 \mathrm{~mm})$, $\overline{P^{2}}$ (4,243,684.28), $\sigma$ (610.27), $C_{v}$ (30.31), $N$ (9.1 number) so that two number of addition rain gauge will be proposed for Anjana Khadi watersheds. The rain gauge density, 1 no. of rain gauge per $93 \mathrm{~km}^{2}\left(836 \mathrm{~km}^{2} / 9\right.$ no. $)$ is suitable for understanding hydrological processes in Anjana Khadi watershed. However, due to rapid population growth in the region, intensification of agriculture, climate change, changes in landuse and river morphology and rapid technology development, it is essential to upgrade the conventional forecasting system. It is suggested to establish two rain-gauge stations at left bank of river Tapi in watershed no. 2 (Bilvan village, Umarpad taluka) and 9 (Ghasiya Medha village, Songudh taluka) (Fig. 14). In addition, two river gauge stations are proposed at Kakrapar weir and Bhamaiya village in bardoli taluka on River Tapi. To find out the accurate location is the scope of further study (Bastin et al. 1984) and may be done by help of Kriging and Entropy method (Awadallah 2012). All these stations should be interlinked with each other through satellite. This existing and additional rain gauges and river 


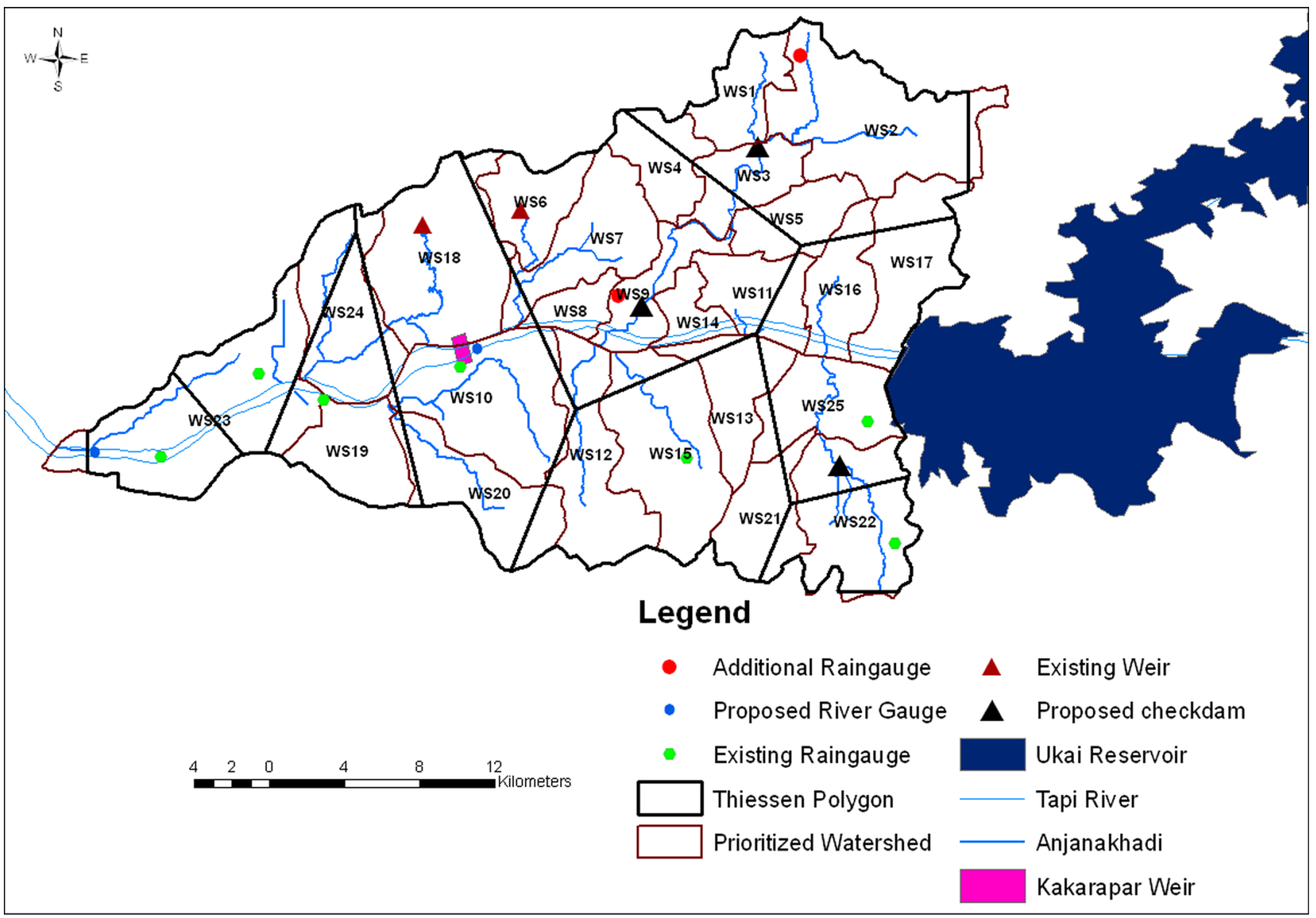

Fig. 14 Theissens polygon, additional rain gauge and proposed River gauge map

gauges will help to provide the information timely which will predicts the accurate amount of runoff coming from ungauged Anjana Khadi watersheds, additional it will helpful for calibration and sensitivity analysis of SWAT model. Result will facilitate the decision makers to forecast the runoff timely for evacuating the people from the low laying area and to reduce the flood mitigation as well as losses at downstream area.

\section{Conclusions}

This study indicates the SWAT is an efficient tool for modeling and to simulate the runoff from Ajana Khadi watersheds. Input data like DEM, watersheds, soil, slope, land use/land cover generated through RS and GIS data is quite applicable to run the SWAT model as well other hydrologic models. This study suggested that predictions of the inflow through analysis of micro-watersheds are very important for flood hazard mitigation and mapping. Such undesirable conditions must be taken into consideration and can be utilized to save the Mandvi, Songadh, Ukai,
Puna and Surat city against flood. For effective mapping of the flood potentiality and vulnerability, there is need of more river and rain-gauge stations. The runoff prone area delineated through this study can be placed under land-use regulation to limit the flood damage potential in those areas. The policy holders and government should emphasize on these areas in terms of building regulations and codes. Rules related to no development or even removal of existing developments can be introduced, especially after flood damages. In addition, the presented result will be helpful for development of advance flood forecasting system (Patel and Srivastava 2013), for preparedness of disaster relief packages and therefore should be integrated with current system which will in turn reduce the flood damages and human lives.

Acknowledgments The first author would like to express their sincere thanks to Dr. M. B. Dholakia, Dr. P. P. Lodha, LDCE, Ahmedanad and Dr. A. K. Sharma, ISRO, Ahmedabad for their valuable suggestions regarding SWAT model development. We also greatly appreciate two anonymous reviewers and chief editor of SWAM for their insightful suggestions and comments. Furthermore, authors would like to deepest thanks to Space Application Centre (SAC-ISRO), National Bureau of Soil Survey and Land Use Planning, 
National Resources Information System, Survey of India and Technical Bulletin- Report on Reconnaissance Soil Survey of Surat District for providing necessary data, facilities and support during the study period.

\section{References}

Abbott MB, Bathurst JC, Cunge JA, O'Connell PE, Rasmussen J (1986) An introduction to the European hydrological systemsysteme hydrologique Europeen, "SHE", 1: history and philosophy of a physically-based, distributed modelling system. J Hydrol 87:45-59

Allen RG (1986) A Penman for all seasons. J Irrig Drain Eng $112: 348-368$

Arnold JG, Williams J, Nicks A, Sammons N (1990) SWRRB; a basin scale simulation model for soil and water resources management. Texas A \& M University Press, College station

Arnold J, Williams J, Srinivasan R, King K (1996) The soil and water assessment tool (SWAT) user's manual, Temple, TX

Awadallah AG (2012) Selecting optimum locations of rainfall stations using kriging and entropy. Int J Civil Environ Eng IJCEE-IJENS, 12

Bastin G, Lorent B, Duque C, Gevers M (1984) Optimal estimation of the average areal rainfall and optimal selection of rain gauge locations. Water Resour Res 20:463-470

CWC (2000-2001) Water year book 2000-2001, Tapi basin, hydrological observation circle, Gandhinagar, Gujarat, India

Du J et al (2013) Hydrological simulation by SWAT model with fixed and varied parameterization approaches under land use change. Water Resour Manag 27:2823-2838

Edet A, Okereke C, Teme S, Esu E (1998) Application of remotesensing data to groundwater exploration: a case study of the Cross River State, southeastern Nigeria. Hydrogeol J 6:394-404

Feldman AD (1981) HEC models for water resources system simulation: theory and experience. Adv Hydrosci 12:297-423

Gosain A, Rao S, Srinivasan R, Reddy NG (2005) Return-flow assessment for irrigation command in the Palleru River basin using SWAT model. Hydrol Process 19:673-682

Gupta M, Srivastava PK (2010) Integrating GIS and remote sensing for identification of groundwater potential zones in the hilly terrain of Pavagarh, Gujarat, India. Water Int 35:233-245

Horton RE (1932) Drainage basin characteristics. Trans Am Geophys Union 13:350-361

Jain SK, Tyagi J, Singh V (2010) Simulation of runoff and sediment yield for a Himalayan watershed using SWAT model. J Water Resour Prot 2:267

Jaiswal RK, Saxena R, Mukherjee S (1999) Application of remote sensing technology for land use/land cover change analysis. J Indian Soc Remote Sens 27:123-128

Jaiswal RK, Saxena R, Mukherjee S (2001) Land use/land cover mapping using IRS 1C LISS III false colour composite: a case study of a part of Shahdol district, Madhya Pradesh. J Trop For 17:33-40

Jensen JR (1996) Introductory digital image processing: a remote sensing perspective, vol Ed. 2. Prentice-Hall Inc

Kannan N, White S, Worrall F, Whelan M (2007) Sensitivity analysis and identification of the best evapotranspiration and runoff options for hydrological modelling in SWAT-2000. J Hydrol 332:456-466

Kumar R, Singh R, Sharma K (2005) Water resources of India. Curr Sci 89:794-811

Lillesand T, Kjefer R (1997) Remote sensing and image interpretation, xii numerous illustration. Wiley, New York, p 612
Melton MA (1957) An analysis of the relations among elements of climate, surface properties, and geomorphology. DTIC document

Monteith J (1965) Evaporation and environment. Symp Soc Exp Biol, p 4

Narsimlu B, Gosain AK, Chahar BR (2013) Assessment of future climate change impacts on water resources of upper sind river basin India using SWAT model. Water Resour Manag 27:3647-3662

Neitsch S, Arnold J, Kiniry J, Williams J, King K (2001) Soil and water assessment tool user's manual, version 2000, Grassland Soil and Water Research Lab Research Center-Texas Agricultural Experiment Station. (http://www.brc.tamus.edu/s)

Pandey V, Panda S, Raghuwanshi N, Sudhakar S (2006) Delineation and parameterization of Banikdih watershed using remote sensing and AVSWAT model. J Indian Soc Remote Sens $34: 143-152$

Panhalkar S (2014) Hydrological modeling using SWAT model and geoinformatic techniques. Egypt J Remote Sens Space Sci

Parmar B, Rao B (2002) Flood control operation for Ukai multipurpose reservoir. ICOLD Symp Reserv Manag Trop Sub Trop Reg Braz, p 278

Patel DP, Dholakia MB (2010) Feasible structural and non-structural measures to minimize effect of flood in lower Tapi basin. WSEAS Trans Fluid Mech, 104-121

Patel DP, Dholakia MB (2010b) Identifying probable submergence area of Surat city using digital elevation model and geographical information system. World Appl Sci J 9:461-466

Patel DP, Srivastava PK (2013) Flood Hazards mitigation analysis using remote sensing and GIS: correspondence with town planning scheme. Water Resour Manag: 1-16

Patel DP, Dholakia MB, Naresh N, Srivastava PK (2012a) Water harvesting structure positioning by using geo-visualization concept and prioritization of mini-watersheds through morphometric analysis in the Lower Tapi basin. J Indian Soc Remote Sens 40:299-312

Patel DP, Gajjar CA, Srivastava PK (2012) Prioritization of Malesari mini-watersheds through morphometric analysis: a remote sensing and GIS perspective. Environ Earth Sci: 1-4

Priestley C, Taylor R (1972) On the assessment of surface heat flux and evaporation using large-scale parameters. Mon Weather Rev 100:81-92

Qiu LJ, FL Yin, Zheng RS (2012) SWAT-based runoff and sediment simulation in a small watershed, the loessial hilly-gullied region of China: capabilities and challenges. Int J Sedim Res 27:226-234

Ritchie JT (1972) Model for predicting evaporation from a row crop with incomplete cover. Water Resour Res 8:1204-1213

Saha PP, Zeleke K, Hafeez M (2014) Streamflow modeling in a fluctuant climate using SWAT: Yass River catchment in south eastern Australia. Environ Earth Sci 71:5241-5254

Singh VP, Woolhiser DA (2002) Mathematical modeling of watershed hydrology. J Hydrol Eng 7:270-292

Srivastava P, Mukherjee S, Gupta M (2008) Groundwater quality assessment and its relation to land use/land cover using remote sensing and GIS. In: Proceedings of international groundwater conference on groundwater use-efficiency and sustainability: groundwater and drinking water issues, Jaipur, India, pp 19-22

Srivastava PK, Mukherjee S, Gupta M (2010) Impact of urbanization on land use/land cover change using remote sensing and GIS: a case study. Int J Ecol Econ Stat 18:106-117

Srivastava P, Mukherjee S, Gupta M, Singh S (2011) Characterizing monsoonal variation on water quality index of river Mahi in India using geographical information system. Water Qual Expo Health 2:193-203 
Srivastava PK, Gupta M, Mukherjee S (2012) Mapping spatial distribution of pollutants in groundwater of a tropical area of India using remote sensing and GIS. Appl Geomat: 1-12

Subramanya K (1994) Engineering hydrology. Tata McGraw-Hill Education

Williams J, Nicks A, Arnold J (1985) Simulator for water resources in rural basins. J Hydraul Eng 111:970-986
Yang J, Reichert P, Abbaspour K, Xia J, Yang H (2008) Comparing uncertainty analysis techniques for a SWAT application to the Chaohe Basin in China. J Hydrol 358:1-23

Young RA, Onstad C, Bosch D, Anderson W (1989) AGNPS: a nonpoint-source pollution model for evaluating agricultural watersheds. J Soil Water Conserv 44:168-173 